\title{
Viability of subitaneous copepod eggs following fish predation on egg-carrying calanoids
}

\author{
Anna M. Redden', Graham R. Daborn \\ Acadia Centre for Estuarine Research, Acadia University, Wolfville, Nova Scotia, Canada B0P 1 X0
}

\begin{abstract}
The viability of subitaneous eggs of the eggcarrying calanoid copepod Eurytemora herdmani was examined following fish ingestion and evacuation. More than 90\% of the copepod embryos recovered intact in the fecal material of Atlantic silversides Menidia menidia hatched within $3 \mathrm{~d}$ of incubation at $12{ }^{\circ} \mathrm{C}$ in both light/dark and completely dark regimes. Percentage hatch was comparable to that for uningested embryos removed from eggsacs and for uningested embryos within eggsacs both attached to, and excised from. maternal copepods. For $E$. herdmani, selective silverside predation on ovigerous females is countered by the capacity of their subitaneous eggs to resist digestion.
\end{abstract}

Zooplankton features that influence prey selection by planktivorous fish include prey size (Ivlev 1961, Brooks 1968. Werner \& Hall 1974, O'Brien et al. 1976), pigmentation (Zaret \& Kerfoot 1975, Hairston 1979a, b) and, in some egg-carrying copepods and cladocerans, the presence of highly visible eggs (Mellors 1975, Hairston et al. 1983). Prior to periods of intense fish predation, many crustaceans produce diapause eggs that are thick-walled, highly pigmented and digestion resistant (Proctor et al. 1967, Mellors 1975). It has been suggested that the production of diapause eggs acts as a survival strategy to offset the costs of selective feeding on egg-bearing females (Hairston \& Munns 1984) and ultimately aids in the perpetuation of endemic populations (Uye 1985).

There has been only one account of digestion resistance in nondiapause copepod eggs. Marcus (1984) showed that both subitaneous ('quick-hatch') and diapause eggs released by the marine copepod Labidocera aestiva are capable of surviving passage through the gut tracts of 2 benthic polychaete species. Egg mortality during gut transport however, was higher for ingested subitaneous embryos. Many other copepod

\footnotetext{
- Present address: Ocean Sciences Centre, Memorial University of Newfoundland, St. John's, Newfoundland, Canada A.1C 5 S7
}

species produce subitaneous eggs that are carried within ovisacs until hatching. As far as we know, there has been no documentation on the viability of ingested subitaneous eggs of ovigerous (egg-bearing) copepods.

Eurytemora herdmani Thompson \& Scott is a planktonic calanoid copepod that produces subitaneous eggs and retains them within a single eggsac until hatching. We know of no accurrences of diapause egg production by $E$. herdmani. This species is a common dominant of zooplankton in temperate brackish waters (Wilson 1932, Daborn \& Pennachetti 1979) and occurs year-round, producing up to 5 or more generations per year (Brown 1984). During spring and early summer, adult E. herdmani, primarily females, have been shown to be a principal food item in the diets of Atlantic silversides Menidia menidia (Gilmurray \& Daborn 1981) and other estuarine fishes (Imrie \& Daborn 1981). On many occasions we have observed large numbers of intact copepod eggs and exoskeletons of adult females in the hind gut tracts of silversides. SEM examinations of these ingested eggs revealed no physical evidence of egg membrane damage or digestive breakdown (Crawford \& Daborn 1986). Egg viability, however, was undetermined.

The present study was conducted to examine the viability of Eurytemora herdmani subitaneous eggs following ingestion and evacuation by a natural fish predator. In some copepods, egg hatching is known to be suppressed by the absence of light (Landry 1975 , Uye \& Fleminger 1976, Uye 1980). Because copepod eggs in fish fecal material are subject to sinking and deposition out of the euphotic zone, the effect of light as a stimulus for E. herdmani embryo development and ecdysis was also investigated.

Methods. Hatch success of Eurytemora herdmani eggs was examined for embryos removed from a sample of live ovigerous females collected during May 1986 from the Cornwallis Estuary at Port Williams, 
Table 1. Eurytemora herdmani. Hatch success of embryos removed from eggsacs of ovigerous females. Incubated at $12{ }^{\circ} \mathrm{C}$ and exposed to $12 \mathrm{~h}$ light:12 h dark (12L:12D), or no light (24D) regimes

\begin{tabular}{|c|c|c|c|c|}
\hline Treatment & Trial & No. embryos & $\begin{array}{c}\% \text { Hatch } \\
2 \mathrm{~d}\end{array}$ & $\begin{array}{c}\% \text { Hatch } \\
3 \mathrm{~d}\end{array}$ \\
\hline \multirow[t]{2}{*}{$12 \mathrm{~L}: 12 \mathrm{D}$} & 1 & 86 & 86.0 & 93.0 \\
\hline & 2 & 70 & 75.7 & 85.7 \\
\hline \multirow[t]{2}{*}{$24 \mathrm{D}$} & 1 & 73 & 98.6 & 100.0 \\
\hline & 2 & 91 & 82.4 & 95.6 \\
\hline
\end{tabular}

Nova Scotia, Canada. Ten females, each bearing an eggsac containing 50 to 75 embryonated eggs, were narcotised with $\mathrm{CO}_{2}$, their eggsacs excised and individual eggs released. A minimum of 70 embryos of undetermined developmental stages were pipetted into each of 4 petri dishes containing $50 \mathrm{ml}$ of membranefiltered $(0.45 \mu \mathrm{m})$ brackish water. The dishes were incubated at $12{ }^{\circ} \mathrm{C}$, the approximate ambient water temperature in the estuary. To examine the importance of light as a stimulus for hatching, 2 dishes were incubated in complete darkness. The remaining 2 dishes were exposed to a simulated day/night cycle of $12 \mathrm{~h}$ of light followed by $12 \mathrm{~h}$ of darkness. Embryo development and hatching were examined at $12 \mathrm{~h}$ intervals in the light-treated trials, and on the 2 nd and 3rd day of incubation, all hatched and unhatched eggs in both light/dark and dark-treated chambers were enumerated.

A zooplanktivorous estuarine fish, the Atlantic silverside, was selected to examine subitaneous egg viability following ingestion and evacuation. Sixteen adult silversides, collected from the Bay of Fundy, were held without food for $12 \mathrm{~h}$ in an aquarium containing filtered seawater. A concentrated sample of zooplankton, numerically dominated by Eurytemora herdmani ovigerous females and adult males, was subsequently added. Silversides were allowed to feed for $6 \mathrm{~h}$ and were then carefully transferred to a foodfree aquarium containing filtered seawater. There was no evidence of regurgitation of recently ingested food as a result of the transfer. Following a gut evacuation period of $9 \mathrm{~h}$, the fish were removed and the released fecal material was collected. Feces were visually examined for the presence of intact copepod eggs and Eurytemora exoskeletons. The collection was then split and placed into each of 2 petri dishes containing $50 \mathrm{ml}$ of filtered seawater. These were incubated at $12{ }^{\circ} \mathrm{C}$ in day/night simulated and completely darkened incubation chambers. Eggs within ovisacs, both attached to and excised from ovigerous females, were set up as control groups to compare hatch success with that of intact embryos evacuated by silversides. After 3 d of incubation all samples were fixed in 5\% formalin-seawater and examined for numbers of hatched and unhatched embryos.

Results. Eurytemora herdmani embryos, removed from the eggsacs of live females and incubated at 12 ${ }^{\circ} \mathrm{C}$, showed a hatch success of greater than $75 \%$ in $2 \mathrm{~d}$ and 85 to $100 \%$ in $3 \mathrm{~d}$ under both light/dark and dark treatment conditions (Table 1). Several stage 1 nauplii were observed following exposure to the initial $12 \mathrm{~h}$ of light. Emergence of nauplii, however, was more frequent after $24 \mathrm{~h}$ in the light/dark treated chambers. The duration of incubation prior to hatching of E. herdmani eggs is comparable to subitaneous egg development times ( 2 to $3 \mathrm{~d}$ ) of many calanoid copepod species reared at similar temperatures (McLaren et al. 1969, Johnson 1980).

The examination of silverside fecal material revealed numerous exoskeletons of Eurytemora herdmani adult females and intact copepod embryos. When incubated at $12{ }^{\circ} \mathrm{C}$ more than $90 \%$ of evacuated intact eggs hatched within $3 \mathrm{~d}$ in both light/dark and dark-treated dishes (Table 2). Percentage hatch of evacuated eggs was not significantly different from percentage hatch of eggs removed from the eggsacs of ovigerous females in either light/dark (Fisher's Exact Test, $\mathrm{p}=$ $0.345)$ or dark ( $p=0.174)$ treatment chambers. All hatched nauplii were positively identified as $E$. herdmani based on comparisons with nauplii produced by ovigerous females in the lab and morphological fea-

Table 2. Eurytemora herdmani. Hatch success of embryos removed from eggsacs of ovigerous females. Incubated at $12^{\circ} \mathrm{C}$ and exposed to $12 \mathrm{~h}$ light:12 h dark (12L:12D), or no light (24D) regimes

\begin{tabular}{|lccc|}
\hline Egg group & Treatment & No. embryos & $\begin{array}{c}\% \text { Hatch } \\
3 \mathrm{~d}\end{array}$ \\
\hline Embryos within & 12L:12D & 1044 & 92.1 \\
fecal material & $24 \mathrm{D}$ & 1355 & 95.0 \\
Attached eggsacs & 12L:12D & 319 & 99.4 \\
(Control 1) & 24D & 284 & 99.3 \\
Excised eggsacs & 12L:12D & 605 & 98.5 \\
(Control 2) & 24D & 801 & 97.2 \\
\hline
\end{tabular}


tures described by Grice (1971). Hatch success of intact copepod embryos in silverside fecal material was similar to percentage hatch in the 2 control groups, i.e. embryos contained in sacs attached to, and excised from, ovigerous females. Subitaneous egg development and ecdysis were not inhibited by absence of light, eggsac excision from females, or by the digestive processes of Atlantic silversides.

Discussion. Copepod eggsacs provide protection for individual embryos from a variety of predators, especially those pelagic and benthic invertebrates with crushing and/or piercing mouthparts and appendages. This protection, however, is costly as clutches carried by ovigerous copepods are typically dark and large and thus highly visible to predators. Crawford \& Daborn (1986) observed individual Eurytemora herdmani clutches of up to 130 eggs and a maximum clutch biomass greater than that of an adult female. This added biomass greatly increases the susceptibility of egg-carrying females to visually feeding predators, particularly zooplanktivorous fishes.

Survival of ingested subitaneous eggs appears to be highly dependent on the specific feeding mechanics and digestive processes of predators. Subitaneous copepod eggs are thin-walled and are thus less protected from mechanical damage and digestion than diapause egg membranes (Hairston \& Olds 1984). Marcus (1984) has shown that subitaneous and diapause eggs of Labidocera aestiva differ in their capacity to survive polychaete gut passage. While the viability of diapause eggs was not altered following ingestion, hatch success of ingested subitaneous eggs was overall $33 \%$ lower than for uningested subitaneous eggs. Because the polychaete predators lacked crushing mouthparts and claws, subitaneous egg mortality was attributed to gut tract processes.

Atlantic silversides ingest food without crushing or piercing their prey. These fish have a protrusile, tubeshaped mouth and capture copepods by inhalation (McComas \& Drenner 1982). Survival of ingested eggs must therefore depend on their resistance to silverside digestive enzymes for the duration of gut residence. Menidia menidia has an undifferentiated gastrointestinal tract and a gut retention time of ca $3 \mathrm{~h}$ at $12{ }^{\circ} \mathrm{C}$ (Peters et al. 1972).

The developmental stage of an ingested subitaneous embryo may also influence its capacity to survive gut passage. During the process of hatching, the inner egg membrane swells osmotically resulting in the rupturing of the outer membrane (Davis 1959). lngested late stage embryos may thus be vulnerable to digestive breakdown and if so, less likely to survive gut transport, particularly when gut residence is of long duration. In this study, the total number and developmental stages of eggs ingested were un- known. Though the number of intact eggs recovered in fecal material may not reflect the total number of eggs ingested, resistance to silverside digestive processes was clearly demonstrated for those Eurytemora eggs evacuated intact.

The egg hatch data in this paper provide the first evidence of digestion resistance in subitaneous embryos of egg-carrying copepods. Intense selective predation on Eurytemora herdmani ovigerous females is offset by the capacity of their subitaneous eggs to remain viable following fish ingestion. In fact, selective predation may actually increase the reproductive success of this species if preferential feeding on egg-carrying females increases the likelihood that nonovigerous females will survive to produce a clutch of eggs.

Subitaneous egg resistance to fish digestion may play an important role in the survival of many other egg-carrying copepod species. It is a particularly good adaptation for copepods inhabiting areas that serve as feeding or 'nursery' grounds for zooplanktivorous fishes. This characteristic has significance for copepod population dynamics and zooplankton-fish interactions and its occurrence in other species should be investigated

Acknowledgements. This research was supported by NSERC Operating Grant A9679 awarded to G. R. Daborn. We are grateful to Peter Comeau for assistance in the field and laboratory. We also thank R. Haedrich, C. Bajdik and B. Sanderson for helpful suggestions and comments during preparation of the manuscript.

\section{LITERATURE CITED}

Brooks, J. L. (1968). The effect of prey size selection by lake planktivores. Syst. Zool. 17: 272-291

Brown, G. S. (1984). Zooplankton of a turbid macrotidal estuary. M. Sc. thesis, Acadia University, Wolfville, N.S.

Crawford, P., Daborn, G. R. (1986). Seasonal variations in body size and fecundity in a copepod of turbid estuaries. Estuaries 9: 133-141

Daborn, G. R., Pennachetti, C. (1979). Zooplankton studies in the southern bight of Minas Basin. Proc. N.S. Inst. Sci. 29: 465-481

Davis, C. C. (1959). Osmotic hatching in the eggs of some fresh-water copepods. Biol. Bull. mar. biol. Lab., Woods Hole 116: 15-29

Gilmurray, M. C., Daborn, G. R. (1981). Feeding relations of the Atlantic silverside Menidia menidia in the Minas Basin, Bay of Fundy. Mar. Ecol. Prog. Ser. 6: 231-235

Grice, G. D. (1971). The developmental stages of Eurytemora americana Williams, 1906, and Eurytemora herdmani Thompson \& Scott, 1897 (Copepoda, Calanoida). Crustaceana 20: $145-158$

Hairston, N. G., Jr (1979a). The adaptive significance of color polymorphism in two species of Diaptomus (Copepoda). Limnol. Oceanogr. 24: 15-37

Hairston, N. G., Jr (1979b). The relationship between pigmen- 
tation and reproduction in two species of Diaptornus (Copepoda). Limnol. Oceanogr. 24: 38-44

Hairston, N. G., Jr, Munns, W. R., Jr (1984). The timing of copepod diapause as the evolutionarily stable strategy. Am. Nat. 123: 735-751

Hairston, N. G., Jr, Olds, E. J. (1984). Population differences in the timing of diapause: adaptation in a spatially heterogeneous environment. Oecologia 61:42-48

Hairston, N. G., Jr, Walton, W. E., Li, K. T. (1983). The causes and consequences of sex-specific mortality in a freshwater copepod. Limnol. Oceanogr. 28: 935-947

Imrie, D. M. G., Daborn, G. R. (1981). Food habits of some immature fish of Minas Basin, Bay of Fundy. Proc. N.S. Inst. Sci. 31: $149-154$

Ivlev, V. S. (1961). Experimental ecology of the feeding of fishes. Yale University Press, New Haven

Johnson, J. K. (1980). Effects of temperature and salinity tolerance on production and hatching of dormant eggs of Acartia californiensis (Copepoda) in an Oregon estuary. Fish. Bull. NOAA 77: 567-584

Landry, M. R. (1975). Dark inhibition of egg hatching of the marine copepod Acartia clausii Giesbr J. exp. mar. Biol Ecol. 20: 43-47

Marcus, N. H. (1984). Recruitment of copepod nauplii into the plankton: importance of diapause eggs and benthic processes. Mar. Ecol. Prog. Ser. 15: 47-54

McComas, S. R., Drenner, R. W. (1982). Species replacement in a reservoir fish community: silverside feeding mechanics and competition. Can: J. Fish. Aquat. Sci. 39: $815-821$

McLaren, I. A., Corkett, C. J., Zillioux, E. J. (1969). Temperature adaptations of copepod eggs from the Arctic to the tropics. Biol. Bull. mar, biol. Lab., Woods Hole 137. 486-493

This note was submitted to the editor
Mellors, W. K. (1975). Selective predation of ephippial Daphnia and the resistance of ephippial eggs to digestion. Ecology 56: $974-980$

O'Brien, W. J., Slade, N. A., Vinyard, G. L. (1976). Apparent size as the determinant of prey selection by bluegill sunfish (Lepomis macrochirus). Ecology 57: 1304-1310

Peters, D. S., Kjelson, M. A., Boyd, M. T (1972). The effect of temperature on food evacuation rate in the pinfish (Lagodon rhomboides), spot (Leiostomus xanthurus) and silverside (Menidia menidia). In: Mitchell, A. L. (ed. ) Proc 26th Ann. Conf. Southeast. Assn Game Fish Comm., Knoxville, p. 637-643

Proctor, V. W., Malone, C. R., DeVlaming, V. L. (1967). Dispersal of aquatic organisms: viability of disseminules recovered from the intestinal tract of captive killdeer Ecology 48: 672-676

Uye, S. (1980). Development of neritic copepods Acartia clausi and $A$. steuri. I. Some environmental factors affecting development and the nature of resting eggs. Bull. Plankton Soc. Japan 27: 1-9

Uye, S. (1985). Resting egg production as a life history strategy of marine planktonic copepods. Bull. mar. Sci. 37 $440-449$

Uye, S., Fleminger, A. (1976). Effect of various environmental factors on egg development of several species of Acartia in Southern California. Mar. Biol. 38: 253-262

Werner, E. E., Hall, D. J. (1974). Optimal foraging and the size selection of prey by bluegill sunfish (Lepomus macrochirus). Ecology 55: 1042-1052

Wilson, C. B. (1932). The copepods of the Woods Hole region Massachusetts. Bull. U. S. Natn. Mus. 158: 1-623

Zaret, T. M., Kerfoot, W. C. (1975). Fish predation on Bosmina longirostris: body size selection versus visibility selection. Ecology 56: 232-237

Manuscript first received: June 25, 1991

Revised version accepted: September 19, 1991 